\title{
福井県大野盆地南東縁の木落断層の活動度とその意義
}

\author{
福井大学教育地域科学部* 山 本 博 文
}

\section{Late Quaternary Activity of the Kiotoshi Fault at the South-Eastern Side of the Ono Basin, Fukui Prefecture, Central Japan and its Tectonic Significance}

\author{
Hirofumi Yamamoto \\ Faculty of Education and Regional Studies, Fukui University, 3-9-1 Bunkyo, Fukui 910-8507, Japan
}

(Received December 19, 2003: Accepted August 5, 2004)

\begin{abstract}
The Kiotoshi fault is a NNW-trending reverse active fault of a length of $3 \mathrm{~km}$ in south-eastern side of the Ono basin, Fukui Prefecture. This reverse fault connects NE-trending right-lateral left-stepping faults, and forms a linear boundary between mountainous land and the basin. To make clear the paleoseismic activity of the fault, the fault morphology, the feature of a fault outcrop in a quarry site, and the ${ }^{14} \mathrm{C}$ dating of buried soil and charcoal samples from the outcrop were examined.

The fault displaced the basement rock and overlying fluvial and fan sediments, and makes a gentle step $0.8 \mathrm{~m}$ high on the fan surface. The amount of vertical displacement of the basement rock is more than $15 \mathrm{~m}$. The displacements of the overlying sediments are from 0.5 to $7 \mathrm{~m}$ or more along the main fault. Buried soil layers, presumably formed by rapid accumulation of fan deposits after faulting events, are present at three horizons in the fan sediments. The calibrated ${ }^{14} \mathrm{C}$ ages of the buried soils are $2,850-1,280$ cal yBP, $5,590-4,620 \mathrm{cal}$ yBP, $11,100-8,810 \mathrm{cal}$ yBP, and the net slips calculated from the vertical displacement of the undeformed buried soil layers are $3.6 \mathrm{~m}, 6.9 \mathrm{~m}$ and 19 to $20 \mathrm{~m}$ from the upper layer. The average slip rate of the fault, calculated from the age and the net slip of the lowermost buried soil layer, is $1.7-2.3 \mathrm{~m} / 1000 \mathrm{yrs}$, i.e. the activity of the fault is classified into A class.

The Kiotoshi fault is a reverse fault accompanying the NE-trending right-lateral left-stepping faults, but the activities (average slip rate) of these strike-slip faults were considered to be low (class $\mathrm{B}$ to $\mathrm{C}$ ). We need, therefore, to investigate the activities of the surrounding strike-slip faults in order to clarify the late Quaternary tectonic activities of this area.
\end{abstract}

Key words: Kiotoshi fault, Sabiraki fault, Paleoseismology, Fukui, Ono basin

\section{§1.はじめに}

中部地方には活発な活断層が多く, 北西一南東走向の 左横ずれ断層およびこれと共役な北東一南西走向の右横 ずれ断層が規則的に配列している (Fig. 1). 北西-南東走 向の活断層系では, 阿寺断層帯とその北西の御母衣断層 帯, 根尾谷断層帯, 柳ヶ瀬断層帯がほぼ等間隔で分布し, その活動度は $\mathrm{A}$ 級ないし $\mathrm{B}$ 級である[活断層研究会 (1991)]. これに対し北東-南西走向の活断層系では, A 級の活動度をもつ跡津川断層がよく知られているが, 他 の活断層の多くは $\mathrm{B}$ 級ないし $\mathrm{C}$ 級であり, 北西-南東走

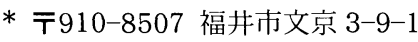

向の断層群に比べ短く，またそれらを横切ってはいない [Kanaori et al. (1992), 活断層研究会 (1991)]. 一方, 最 近の GPS 連続観測による地殼変動デー夕から, 新潟か ら神戸にかけて延びる幅数十〜200 km の変形集中帯 (新潟一神戸構造帯) が提唱され, いくつもの内陸直下型 地震がこの変動帯で発生している [Sagiya et al. (2000), 䉆谷 (2001)].

木落断層は福井県大野市佐開南方から木落北方にかけ てほほ南北に延びる逆断層であり [山本・加藤 (1997)]， GPS 連続観測から推定されている北東－南西方向に連 なる变形集中帯の一角に位置している (Fig. 1). 断層は 大野盆地とその東側山地との直線的な境界をなしてお 


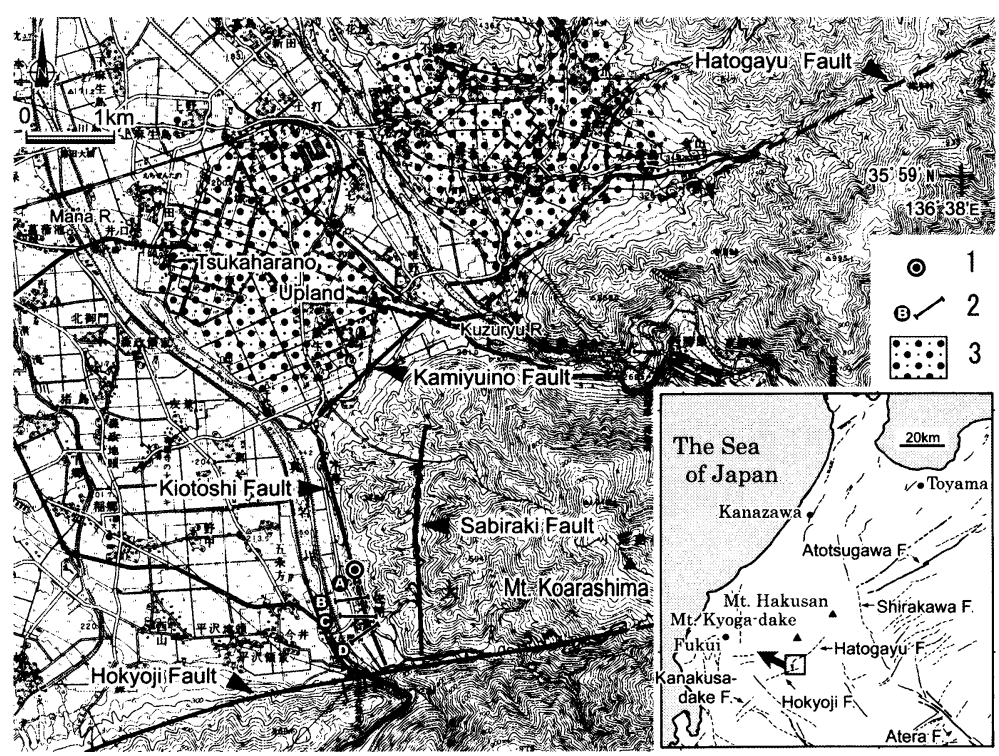

Fig. 1. Location of the Kiotoshi fault and adjacent active faults [after Research Group for Active Faults of Japan (1991)]. Solid and dashed lines denote active faults and presumed active faults. The topographic map is a part of "Arashima-dake" at the scale of 1:50,000 of the Geographical Survey Institute.

1: studied outcrop site of the Kiotoshi fault, 2: topographic profiles shown in Fig. 2, 3: distribution of the debris avalanche deposits from Mt. Kyogadake.

り，全長は約 $3 \mathrm{~km}$ と短い，木落断層東側の山腹には, これとほぼ平行に佐開断層が通っている，木落断層，佐 開断層の北東には中部地方の右横ずれ断層系に属する 上唯野断層, 劦鳥ヶ湯断層, 跡津川断層が, また南西には 宝慶寺断層, 釛草岳断層が断続的に連なっており[活断 層研究会 (1991)]，木落断層，佐開断層はちょうど宝慶 寺断層之左㕍行状に配列する上唯野断層を橋渡しするよ うに南北に延びている (Fig. 1).

山本・加藤 (1997) は佐開北方の土砂採取場に見出さ れた逆断層露頭(部)の予察的な観察結果を報告している が, 今回, 木落断層の活動度等を明らかにするために, この露頭の詳細な観察, 埋没土㙵の ${ }^{14} \mathrm{C}$ 年代測定を行う とともに，周辺の地形計測を行った。 また福井県恐竜博 物館展示のための断層露頭のはぎ取り作業の際, 断層基 部においてピットの掘削を行った．本論文では以上の調 查結果をまとめるとともに，木落断層が示す活動度の意 義について考察した.

\section{§2. 木落断層, 佐開断層の概要之断層地形}

福井県東部に位置する大野盆地は, 東西約 $8 \mathrm{~km}$, 南

活) 現在は土捨て場として利用されており, 露頭がな くなりつつある
北約 $9 \mathrm{~km}$ のほぼ正方形をした山間盆地であり，南側か ら真名川が，東側から九頭竜川が盆地内に流れ込んでい る. 盆地南東部には小荒島岳を中心とする山体の張り出 しが見られ, 張り出した山体の西縁は木落断層によっ て, 北西縁は上唯野断層によって, また大野盆地南縁は 宝慶寺断層によって区切られている. 上唯野断層北西に は塚原野台地が広がっている (Fig. 1).

木落断層は, 佐開北方の土砂採取場で見出された断層 露頭での形状, および盆地と山地との直線状の境界か ら，ほぼ南北に延びる逆断層とされている[山本・加藤 (1997)]。 木落断層の南方延長は東北東一西南西に延びる 宝慶寺断層付近までであり，その南側山地には木落断層 の延長部の存在を示唆するリニアメントは認められな い.また北方では木落集落の北, 上唯野断層付近までリ ニアメントが延びている，上唯野断層北西に広がる塚原 野台地は, 大野盆地北東に位置する経ヶ岳の南西麓で発 生した岩屑なだれが形成した高まりであり，台地上には かつて多くの流机山が分布していた[池田・大八木 (1996), 山本・土田 (2002)]. 塚原野台地の形成時期と しては, 三村 (2001) は塚原野台地の岩屑なだれ堆積物 を覆う土㙵上部の泥炭質黒土の ${ }^{14} \mathrm{C}$ 年代, および経ヶ岳 南西の薄い岩屑なだれ堆積物に覆われた黒土の ${ }^{14} \mathrm{C}$ 年代 から， 6,700 年前から 5,000 年前の間としている. しか 


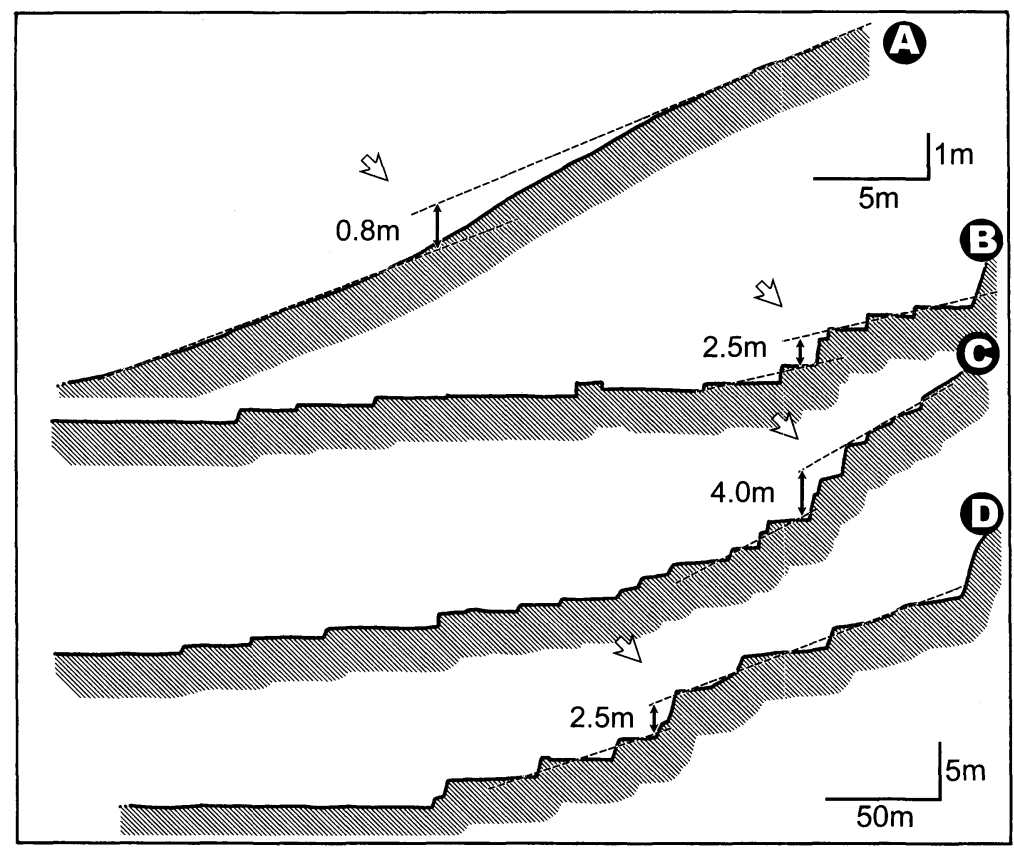

Fig. 2. Topographic cross sections across the Kiotoshi fault. Line A is situated near the outcrop site of the Kiotoshi fault. Lines B, C and D are in and around the Sabiraki Settlement. See Fig. 1 for locations of the cross sections.

し塚原野台地では，岩屑なだれ堆積物を覆う土壌最下部 から姶良 $\mathrm{Tn}$ 火山灰 (AT) 起源と考えられる屈折率 1.500 付近を示すバブルウォール型火山ガラスの濃集層 が確認されており, 台地面の形成は AT 降灰直前, すな わち約 3 万年前と推定される. 後述する木落断層の平均 変位速度および台地面の形成時期からすると, 塚原野台 地面上に明瞭な段差が認められないことは, 木落断層が 塚原野台地域までは延びていないことを示しているとい える.

佐開集落付近では半径 $300 \mathrm{~m}$ ほよ゙の小扇状地が東側 山地加盆地側へと張り出している、木落断層はこの小 扇状地を横切っており, 比高 2.5〜 4.0 m の西落ちの小 崖が小扇状地面上に連なっている (Figs. 2-B〜D, 3). 小 崖は佐開集落南方で段丘と汇濫原を区切る比高数 $\mathrm{m}$ の 小崖に連なっている (Fig. 3).この小崖については, 断層 崖の可能性むあるが, すぐ西側を流れる真名川の側方侵 食によって形成された可能性むあり，はっきりしない。 また山本・加藤 (1997) が断層露頭を報告している佐開 集落北方の小扇状地面でも緩やかな西落ち約 $0.8 \mathrm{~m}$ の 段差が認められる (Fig. 2-A). 断層北部, 木落集落付近 では, 高さ $20 \sim 30 \mathrm{~m}$ の直線的な急崖が山地と盆地との 境界にあり, 急崖上 (山地側) には狭いながら扇状地状 の緩斜面や平坦面が認められる (Fig. 3).
佐開断層は木落断層の東側約 $0.5 \sim 1 \mathrm{~km}$ の山腹を通 る $\mathrm{N}-\mathrm{S}$ 走向, 長さ約 $3 \mathrm{~km}$ の活断層である. 村井・金子 (1975) は西側隆起の活断層として図示し, 活断層研究会 (1980, 1991) は山地高度の不連続, 溝状の凹地, 低断層 崖から確実度 II, 活動度 B C 級, 東側隆起の活断層と している. 空中写真判読では, 南北に連なる鞍部列が明 瞭であり，その西側で山地斜面高度が一段高くなってい る (Fig. 3). 山地斜面の高度変化からすると, 佐開断層は 村井・金子 (1975) が示しているように西側隆起の断層 である可能性が高い. 佐開断層は東傾斜の逆断層である 木落断層のすぐ東側 (山側) にほぼ平行に通っているこ と, 木落断層とは逆の西側隆起を示すということからす ると, 断層面の傾斜方向は明らかになっていないが，木 落断層のバックスラストの可能性がある. なお活断層研 究会 $(1980,1991)$ が述べている佐開集落南側の低崖に ついては, その位置が佐開断層のリニアメントからは $500 \mathrm{~m}$ ほど西にずれており, 木落断層の延長部に位置す ることから, 佐開断層の変位を示すあのではないといえ る.

\section{§3. 土砂採取場の木落断層露頭}

佐開集落の北約 $0.5 \mathrm{~km}$ の土砂採取場において, 木落 断層の露頭が見出された [山本・加藤 (1997)]. 土砂採 


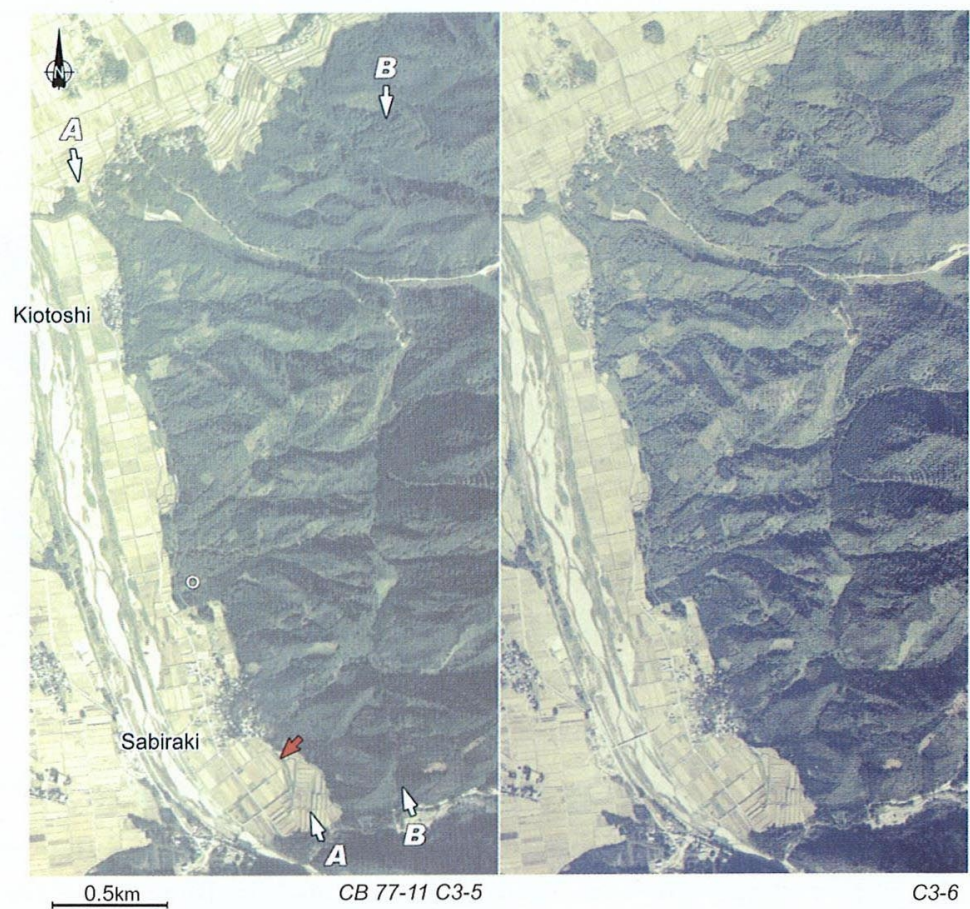

Fig. 3. Stereo-photographs along the Kiotoshi fault and the Sabiraki fault. Open circle shows the studied outcrop site. A red arrow shows the low cliff north of the Sabiraki Settlement.

A: Kiotoshi fault, B: Sabiraki fault.

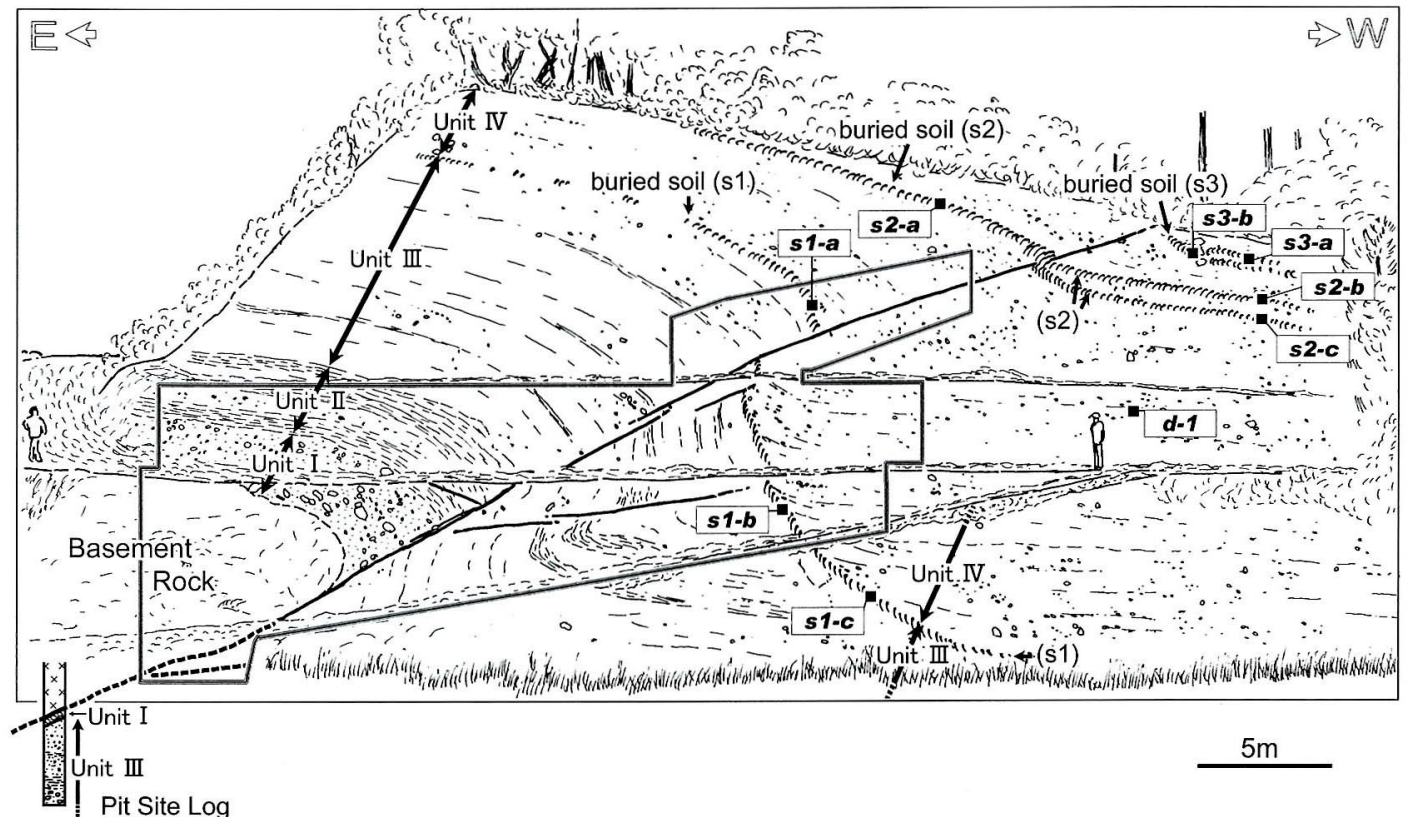

Fig. 4. Sketch of the fault outcrop about $500 \mathrm{~m}$ north of the Sabiraki Settlement. The solid squares show the sampling points for ${ }^{14} \mathrm{C}$ dating. The polygonal frame shows the portion of detailed sketches in Fig. 6. 


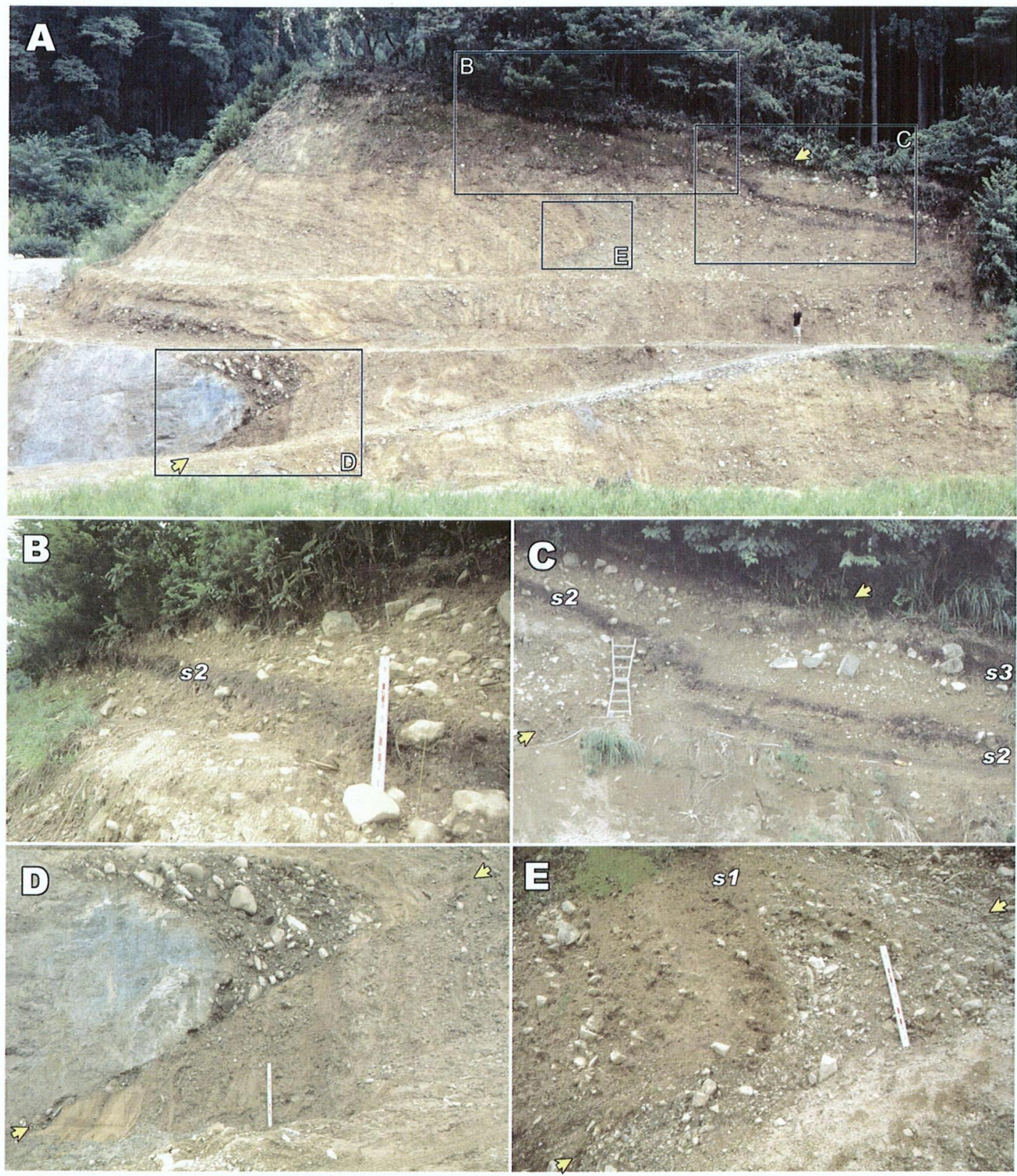

Fig. 5. Outcrop photographs of the Kiotoshi fault. Yellow arrows show the position of the main fault. Squares B, C, D and E in photograph A correspond to the area of the photograph B, C, D and E in this figure.

A: whole outcrop, B: buried soil layer (s2) of the hanging wall side, C: buried soil layers (s2 and s3) dislocated by the fault, D: basement rock and fluvial gravels contacted with the deformed fan deposits of the footwall side by the fault, E: buried soil layer (s1) cut by the fault.

取場は, 東側山地から張り出した半径約 $500 \mathrm{~m}$ の小扇 状地に作られて抢り, 採取場周辺の小扇状地面は西ない し南西に約 $10^{\circ}$ 傾斜している. 断層は土砂採取場の南側 と北東側の壁面に認められ, 両者加求められた断層の
走向は $\mathrm{N} 20^{\circ} \mathrm{W}$ である. 調查は露頭状況の良好な南側の 壁面において行った，南側壁面は小扇状地の傾斜方向と 平行な $\mathrm{N} 60^{\circ} \mathrm{E}$ 方向に約 $45^{\circ}$ の傾斜で作られており，断 層の走向方向とはほぼ直交している. 


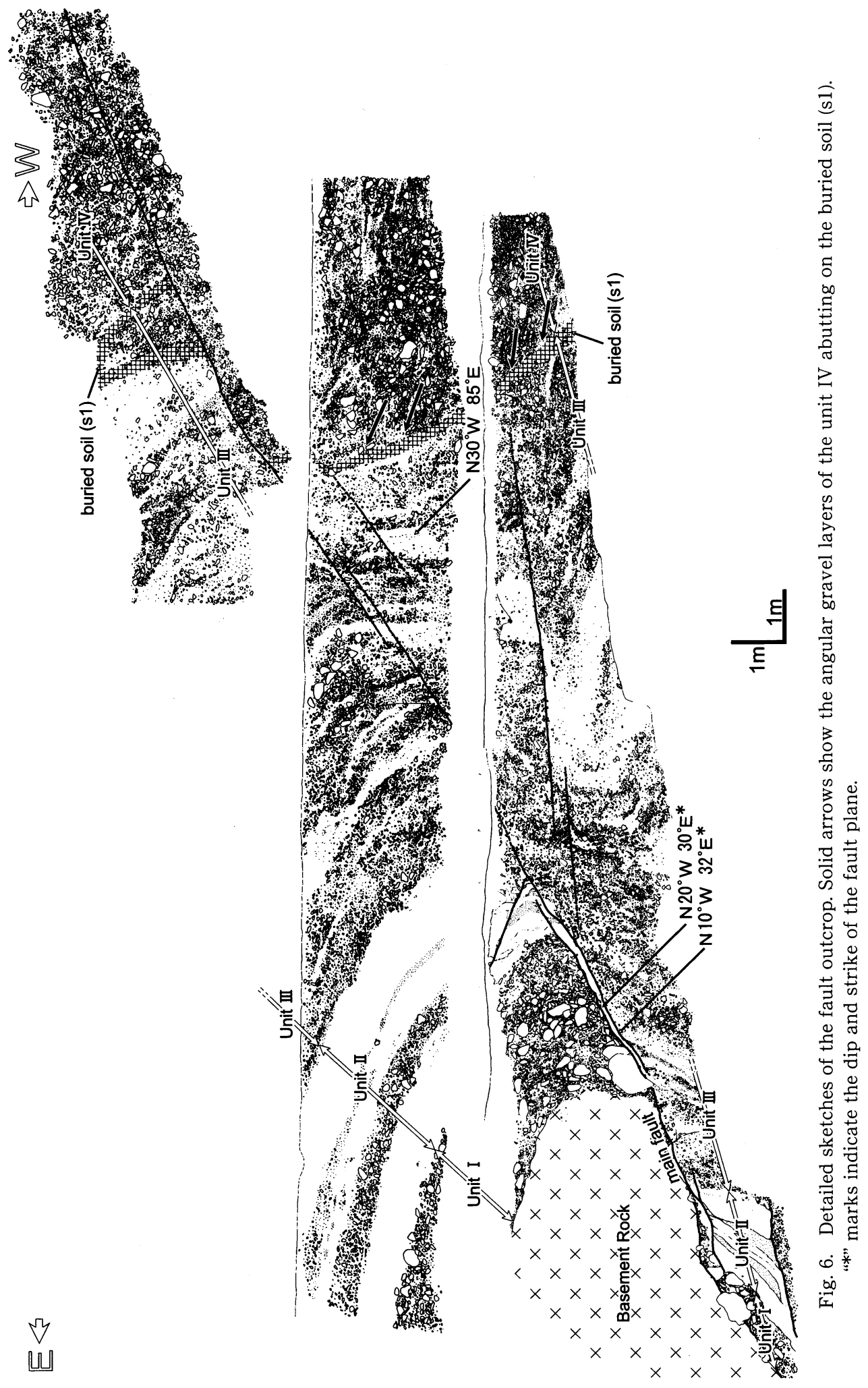


土砂採取場南側壁面には基盤岩およびこれを覆う砂碟 層が露出し, 明瞭な東傾斜の逆断層がこれらを变位させ ている (Figs. 4〜6). 以下, この断層露頭における層序, 断層の形態と地層の変位・変形, および変位量について 述べる.

\section{1 断層露頭における層序}

この断層露頭では, 断層東側（上盤側）に基盤岩およ びこれを覆う円碟層, 砂泥層, 角碟層が, 西側 (下盤側) にはおもに角砶層が露出している.この露頭において堆 積層を, 下位より I 層, II 層, III 層, IV 層に区分した (Fig. 4). 以下，各層について記載する.

基盤岩は船津型花崗岩および貫入岩からなり, 幅 50 $\mathrm{m}$ 以上にわたって破砕されている [Hattori and Yamamoto (1999)]. 基盤上面は侵食により平坦化されてお り, 採石場東半部ではほぼ同じ高さに認められる. 基盤 岩を不整合に覆うＩ層はよく円磨された中碟〜大碟を主 体とする碟層である. 碟種として真名川上流域に分布す る本戸層起源の赤褐色を呈する特徴的な砶岩, 砂岩が認 められることから, I 層は土砂採取場西方を流れている 真名川の流路堆積物と考えられる. 層厚は上盤側では $1.4 \mathrm{~m}$ であるが，下盤側では露頭下部にわずかに露出す るのみであり, 不明である (Fig. 6). II 層は砂層, 泥層か らなり, 上盤側では厚さ $0.1 〜 0.4 \mathrm{~m}$ の角碟層を挟む. 碟 はおもに花崗岩, 安山岩からなり, ほとんど円磨されて いない. また細粒堆積物中には屈折率 1.500 前後を示す 無色透明なバブルウォール型火山ガラスが含まれてい る. 層厚は上盤側で $2.5 \mathrm{~m}$ である. III 層はおもに角碟層 からなり, 厚さ数十 $\mathrm{cm}$ の砂層, 泥層を挟む. 碟は東側 山地を構成する花崗岩, 安山岩のほとんど円磨されてい ない角礫を主とすることから，東側から供給されたもの と考えられる，基質はやや泥質な砂を主体とし，全体に 黄褐色を帯びている. III 層の層厚は, 上盤側では約 $8 \mathrm{~m}$ であるが, 下盤側では変形し，いくつもの副断層に切ら れているため, はっきりしない. IV 層最上部には不明瞭 ながら埋没土壌 (s1 とする) が認められ, 一部では暗褐 色を呈している (Figs. 4, 5-E). IV 層は III 層と同様な角 礫層からなり, 砂層を挟む. III 層に比べ基質が砂質であ り，黄褐色をほとんど帯びていない，層厚は露頭東端部 で $2 \mathrm{~m}$ ほどであるが西側ほど厚くなり, 下盤側では約 $15 \mathrm{~m}$ となっている. IV 層中には 2 層準に黒褐色を呈す る埋没土壤が挟まれており, 下位より $\mathrm{s} 2, \mathrm{~s} 3$ とする (Figs. 4, 5-B, C). s2 は上盤側では東側ほど埋没深度が浅 くなり, 小扇状地面に接するようにして途切れている.

下盤側では厚さ $0.3 \sim 0.4 \mathrm{~m}$ の角碟層を挟んで 2 層に分 かれており，その上面深度は $2.0 \mathrm{~m}$ および $2.6 \mathrm{~m}$ であ る. s3 は下盤側のみに挟まれており, 断層近傍でめくれ
上がって地表に接している. 埋没土壤の上面深度は約 $0.8 \mathrm{~m}$ である.

\section{2 断層の形態亡地層の変位・変形}

断層は基盤岩およびこれを覆う堆積層を変位・変形さ せ,さらに地表面に落差約 $0.8 \mathrm{~m}$ の緩やかな段差を形成 している (Figs. 2-A, 4). 断層面の走向は $\mathrm{N} 10 \sim 20^{\circ} \mathrm{W}$,

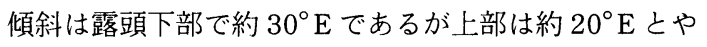
や緩傾斜となっている. またいくつかの副断層も認めら れる (Fig. 4).

主断層に沿った変位量は, s1 では 3〜 $4 \mathrm{~m}$, 平行する 副断層による変位も含めると 4 $5 \mathrm{~m}, \mathrm{~s} 2$ では $0.5 \sim 1 \mathrm{~m}$ である (Fig. 4). I 層, II 層上面は主断層に沿って約 $7 \mathrm{~m}$ 変位しているが, 露頭基部に見られる副断層により, さ らに $2 \mathrm{~m}$ 以上変位している (Fig. 6). また基盤上面の垂 直変位量を求めるため, 露頭東側基部において深さ約 5 $\mathrm{m}$ のピットを掘削したところ, 地表から深さ $2.0 \mathrm{~m}$ まで が破砕された基盤岩, 主断層を挟んでその下に厚さ 0.2 $\mathrm{m}$ の円砶層 (I 層), 副断層を挟んでその下は砂層を挟む 角碟層 (III 層) となっており (Fig. 4), 下盤側の基盤ばか りでなくI層, II 層にも達しなかった，すなわち基盤上 面の垂直変位量は, 上盤側基盤上面とピット底面との高 度差 $11.2 \mathrm{~m}$ に I 層, II 層の厚さ $(3.9 \mathrm{~m})$ を加えた 15.1 $\mathrm{m}$ を超えていると推定される.

断層によるひきずり変形は, I 層, II 層, III 層を中心 に明瞭に認められる。上盤側では, 断層から離れた露頭 東側の III 層は西に $9^{\circ}$ と地表面に平行に傾斜している が, 断層近傍では $45^{\circ}$ を超える急傾斜となっている (Figs. 4,6). I 層, II 層も同様である. ひきずり変形が及 んでいる幅は I 層では数 $\mathrm{m}, \mathrm{IV}$ 層では $10 \mathrm{~m}$ 以上となっ ている. 下盤側では, 断層から離れた露頭西側の III 層, IV 層は西に $9^{\circ}$ と地形面に平行に傾斜しているが, 断層 近傍ではより強く変形しており, 特に I 層, II 層, III 層 下部は逆転し, いくつかの小断層に切られ, 複雑な様相 を呈している (Fig. 6). 断層による変形の範囲は露頭下 部では $10 \mathrm{~m}$ を超えているが, 上部では約 $1 \mathrm{~m}$ と狭く なっている (Fig. 4).

\section{3 断層変位量}

主断層に沿った各層の変位量は前述のとおりである が，断層のひきずりによる変形が明瞭であり，それらあ 考慮した総変位量を以下のように推定した. なお断層面 に接した砅の下面にはほぼ傾斜方向に伸びているスリッ ケンラインが認められ, 横ずれ成分はないものとした。

基盤上面の垂直変位量は, 露頭東部におけるピット掘 削から $15.1 \mathrm{~m}$ 以上と推定される. 露頭基部における断 層傾斜角は約 $30^{\circ}$ であり, 総変位量は $30 \mathrm{~m}$ 以上と求め られる. 
III 層, IV 層は小扇状地を構成する砂啋層であり, 断 層変形が及んでいない地点では扇状地面と平行な西に 9の傾斜を示している. III 層最上部に位置する s1 の垂 直変位量を, 上盤側, 下盤側の変形の及んでいない地点 の $\mathrm{s} 1$ を傾斜 $9^{\circ}$ で延長することにより求めたところ, 12〜 $13 \mathrm{~m}$ となった. 断層傾斜角を $30^{\circ}$ とすると総変位 量は 19〜20 m と求められる.

s2 は上盤側では東側ほど緩傾斜となり, 地表に接す るようにして途切れている. 一方下盤側では 2 層に分か れている. そこで $\mathrm{s} 2$ の基準面を，上盤側では変形の及 んでいない地表面とし， s1 と同様に垂直変位量を求め ると, 下盤側上位の埋没土壤で $2.9 \mathrm{~m}$, 下位の埋没土壤 で $3.4 \mathrm{~m}$ となる. III 層上部を切る断層の傾斜角は約

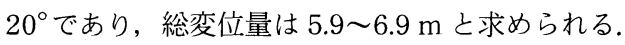

s3 は下盤側では断層近傍でめくれ上がり, 地表に接 して途切れている. 上盤側には相当する埋没土壤は見当 たらない，そこで上盤側における基準面を現在の地表面 とすると, 垂直変位量は断層付近で認められる地表面の 段差 $0.8 \mathrm{~m}$ に地表面からの深さ $0.8 \mathrm{~m}$ を加えた $1.6 \mathrm{~m}$ となる. 断層の傾斜角を $20^{\circ}$ とすると総変位量は $3.3 \mathrm{~m}$ となる。

\section{$\S 4 .{ }^{14} \mathrm{C}$ 年代測定亡火山灰の同定}

この露頭において, 埋没土壤を中心に試料を採取し, 加速器質量分析法 (AMS 法) による放射性炭素同位体 年代測定を行った. Fig.4 に試料採取位置を, Table 1 に 測定結果を示す.

測定した試料は埋没土壌 $\mathrm{s} 1$ では上盤側 1 地点 (s1-a), 下盤側 2 地点 (s1-b, s1-c), s2 では上盤側 1 地点 (s2-a),
下盤側では上位 1 地点 (s2-b), 下位 1 地点 (s2-c), s3 で は 2 地点 (s3-a, s3-b) である. また IV 層中部に含まれて いた炭化木片 (d-1) も採取し測定を行った。得られた ${ }^{14} \mathrm{C}$ 年代は, s1 では 9,540 $770 \mathrm{yBP}(\mathrm{s} 1-\mathrm{a}), 9,530 \pm 70 \mathrm{yBP}$

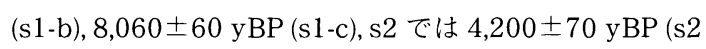
-a), 4,330 \pm 80 yBP (s2-b), 4,780 \pm 70 yBP (s2-c), s3 で

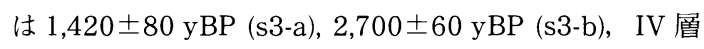
中の炭化木片は $6,440 \pm 60 \mathrm{yBP}(\mathrm{d}-1)$ であった. 以上よ り, 各埋没土壤の年代 (暦年補正年代) は, 埋没土壤 $\mathrm{s} 1$ では $11,100 \sim 8,810 \mathrm{cal} \mathrm{yBP,} \mathrm{s} 2$ では 5,590 4,620 cal yBP, s3 では 2,850〜 1,280 cal yBP となる.

また II 層中に混入していた火山ガラスは，その形態・ 屈折率から約 2.6 2.9 万年前 [町田・新井, 2003] の姶 良 Tn 火山灰と思われる. 火山ガラスは II 層全体にわ たって散在しており, II 層は AT 降灰以降（直後?）の 堆積層と推定される.

\section{§ 5. 木落断層の活動度・活動履歴とその意義}

木落断層の活動度および活動履歷を埋没土壤の ${ }^{14} \mathrm{C}$ 年 代および变位量から検討する. 小扇状地堆積物中には埋 没土壤 $\mathrm{s} 1, \mathrm{~s} 2, \mathrm{~s} 3$ が挟まっている. 埋没土壤は断層近傍 を中心に認められ，一部では上位の砂碎層がこれをア バットして覆っている (Fig. 6).このような産状から, 埋 没土壤は断層活動に伴い小扇状地面上に形成された段差 が急激に埋積されることにより, 地表付近の土壌が埋没 し形成されたと考えられる。すなわち埋没土壇上面は断 層変位直前の小扇状地面を示しており, 埋没土㙵の年代 は, ほぼ断層の活動時期を示すものと考えられる。

$\mathrm{s} 3$ の ${ }^{14} \mathrm{C}$ 年代は, $2,850 \sim 1,280 \mathrm{cal} y \mathrm{yBP}$ と幅があるも

Table 1. Results of ${ }^{14} \mathrm{C}$ dating of buried soil and charcoal samples from the fault outcrop. All data were determined by AMS at Institute of Geological and Nuclear Sciences Ltd. of New Zealand. Calibrated years are based on INTCAL98 [Stuiver et al., 1998].

\begin{tabular}{|c|c|c|c|c|}
\hline Sample No. & $\begin{array}{c}\text { measured } \\
\text { material }\end{array}$ & $\begin{array}{c}\text { conventional }{ }^{14} \mathrm{C} \text { age } \\
( \pm 1 \sigma) \text { yrs BP }\end{array}$ & $\begin{array}{c}\delta^{13} \mathrm{C} \\
\text { (permil) }\end{array}$ & $\begin{array}{l}\text { calibrated age } \\
( \pm 1 \sigma) \text { cal BP }\end{array}$ \\
\hline$s 1-a$ & soil & $9,540 \pm 70$ & -24.2 & $11,100-10,900$ \\
\hline$s 1-b$ & soil & $9,530 \pm 70$ & -24.9 & $11,100-10,700$ \\
\hline $\mathrm{s} 1-\mathrm{c}$ & soil & $8,060 \pm 60$ & -23.9 & $\begin{array}{l}9,030-8,980 \\
8,880-8,870 \\
8,830-8,810 \\
\end{array}$ \\
\hline s2-a & soil & $4,200 \pm 70$ & -19.3 & $\begin{array}{l}4,840-4,790 \\
4,770-4,620 \\
\end{array}$ \\
\hline$s 2-b$ & soil & $4,330 \pm 80$ & -20.3 & $\begin{array}{l}5,030-5,020 \\
4,970-4,830\end{array}$ \\
\hline $\mathrm{s} 2-\mathrm{c}$ & soil & $4,780 \pm 70$ & -19.4 & $\begin{array}{l}5,590-5,460 \\
5,360-5,330\end{array}$ \\
\hline s3-a & soil & $1,420 \pm 80$ & -20.1 & $1,390-1,280$ \\
\hline$s 3-b$ & soil & $2,700 \pm 60$ & -21.5 & $2,850-2,750$ \\
\hline$d-1$ & charcoal & $6,440 \pm 60$ & -24.4 & $\begin{array}{l}7,430-7,310 \\
7,300-7,290 \\
7,280-7,270\end{array}$ \\
\hline
\end{tabular}


のの,この頃に断層活動があったと思われる. 変位量は $3.3 \mathrm{~m}$ である. $\mathrm{s} 2$ は下盤側で上下 2 枚に分かれており, 上位の埋没土壌は下位に比へ数百年新しい ${ }^{14} \mathrm{C}$ 年代を示 している. 2 層の埋没土壤の形成については，1) 地震直 後には段差を完全に埋めてしまうほどの埋積は行われ ず，数百年後の土砂の供給により再度埋積された，また は2) 数 100 年後, 別の断層活動があり,これによって 新たに段差が形成され，埋没土㙥が形成されたという 2 通りの解釈が考えられる. $\mathrm{s} 2$ の ${ }^{14} \mathrm{C}$ 年代は, 上盤側( $\left.\mathrm{s} 2-\mathrm{a}\right)$ と下盤側上位 (s2-b) が比較的近い值を示していること, 上位と下位の年代差が数 100 年程度と比較的短いこと, また現在の地表面にも, 落差 $0.8 \mathrm{~m}$ の段差が埋積されず に残されていることから判断して, 下盤側 2 枚の埋没土 㙵の形成過程としては前者の可能性が高いと考えられ る. 以上より, 下位の埋没土壤を断層活動直後に形成さ れた埋没土壤とすると, 活動時期は 5,590〜 5,330 cal $\mathrm{yBP}$, 変位量は $\mathrm{s} 3$ 埋没時の変位量 $3.3 \mathrm{~m}$ を除いて $3.6 \mathrm{~m}$ と求められる. $\mathrm{s} 1$ の ${ }^{14} \mathrm{C}$ 年代は $11,100 \sim 8,810 \mathrm{cal} \mathrm{yBP}$ であり,この頃, 断層活動があったと思われる. $\mathrm{s} 1$ の変位 量は 19 20 mであり, $\mathrm{s} 3$ 抢よび $\mathrm{s} 2$ 埋没時の変位量 6.9 $\mathrm{m}$ を除くと $12 \sim 13 \mathrm{~m}$ となる. この值は $\mathrm{s} 3$ 埋没時の変 位量 $3.3 \mathrm{~m}, \mathrm{~s} 2$ 埋没時の $3.6 \mathrm{~m}$ に比べ明らかに大きく, $\mathrm{s} 1$ 埋没時の一度の活動でこれだけ変位したとは考えに くい．また時間間隔も 5,800～3,200 年とやや大きく， s 1 と 2 の間に打いても断層活動があった可能性が高い.

平均変位速度は最も下位の埋没土袞である $\mathrm{s} 1$ を基準 とすると, s1 の年代である 11,100 8,810 cal yBP，お よび $\mathrm{s} 1$ の変位量である 19 20 $\mathrm{m}$ より, $1.7 \sim 2.3 \mathrm{~m} /$ 1,000 年となり, 木落断層は $\mathrm{A}$ 級の活動度をもっている ことになる. 1 回の活動による変位量は $\mathrm{s} 3$ 埋没時の変 位量が $3.3 \mathrm{~m}, \mathrm{~s} 2$ 埋没時が $3.6 \mathrm{~m}$ であることから，3〜4 $\mathrm{m}$ と思われる. 活動間隔は $\mathrm{s} 2$ と $\mathrm{s} 3$ の年代值に基づく と, s3 の值がばらついているためはっきりしないが, $2,500 \sim 4,500$ 年程度と推定される.

木落断層の長さはわずか $3 \mathrm{~km}$ であり，このように短 い活断層が単独で単位変位量が $3 \sim 4 \mathrm{~m}$ と大きく, 平均 変位速度が $1.7 \sim 2.3 \mathrm{~m} / 1,000$ 年という $\mathrm{A}$ 級の活動をす るとは考えにくい，木落断層は左雁行状に配列する北東 一南西方向にのびる右横ずれ断層群をつなぐように南北 に延びている逆断層であり，これらの横ずれ断層群の活 動に伴う圧縮場で形成されたと考えられる. 右横ずれ断 層群は, 北東側より, 跡津川断層, 活火山である白山を 挟んで鳩ヶ湯断層, 上唯野断層, 宝慶寺断層, 金草岳断 層と連なっている(Fig. 1)。これらの断層群のうち跡津 川断層は, 最新の活動が 1,858 年（安政 5 年）の飛越地 震時 $(M=7.0 \sim 7.1)$, 活動間隔は $1,100 \sim 5,100$ 年であり
[跡津川断層トレンチ発掘調査団・他 (1989)], 平均変位 速度は河岸段丘のずれから $2 \sim 3 \mathrm{~m} / 1,000$ 年の右横ず れ, 扇状地面のずれから $3 \sim 5 \mathrm{~m} / 1,000$ 年の右横ずれと A 級の活動度を示している [東郷・岡田 (1983)].

これに対し, その南西に連なる鳩っ湯断層, 上唯野断 層, 宝慶寺断層, 金草岳断層は, いずれもその活動度が B 級以下とされている [活断層研究会 (1991)]．鳩ヶ湯 断層は 1961 年の北美濃地震 $(M=7.2)$ 直後の森本・松 田 (1961)による地質調査により，規則的な先第四系の 変位, および幅 $10 \mathrm{~m}$ 以上の粘土を伴う破砕帯の存在か ら明らかにされた断層であるが，北美濃地震との関連は 明らかになっていない. 活断層研究会 (1991) は, 鳩ヶ湯 断層については直線状谷, 古期岩類の分布不連続, 断層 露頭から確実度 II III, 活動度 C, 上唯野断層について は段丘面のずれから確実度 II, 活動度 B, 宝慶寺断層に ついては尾根・谷の屈曲加 確実度 II, 活動度 $\mathrm{B} \sim \mathrm{C}$, 金草岳断層については尾根・谷の屈曲加ら確実度 II, 活 動度 B としている。 また中田・今泉 (2002) は上唯野断 層および宝慶寺断層の一部を推定断層として示している が, 鳩ヶ湯断層, 佐開断層, 木落断層は活断層/推定活断 層として示していない. 空中写真判読では, 金草岳断層 に沿う谷の系統的な屈曲や鞍部列が明瞭であるが，鳩ヶ 湯断層, 上唯野断層, 宝慶寺断層では変位地形は明瞭で はない．また詳細な断層調査もほとんど行われておら ず，活動度や最新活動時期を示すデー夕は得られていな い. 微小地震活動を見ると, 跡津川断層沿いに活発な地 震活動が認められ，その活動域は北西-南東走向の御母 衣断層を越え, 白山付近まで達し, 発震機構も跡津川断 層沿いの地震之同様である [三雲・和田, 1983]. しか しその南西側, 木落断層周辺では, 地震活動はあまり活 発ではなく, 右横ずれ断層群に沿った震源の帯状配列屯 あまり明瞭でない [竹内・平野, 1985 など].

一方, Hashimoto and Jackson (1993) は 1883 年よ り行われている三角測量などの結果から，上記右横ずれ 断層群を含む信濃川地震帯一跡津川断層一有馬一高柣構造 線一中央構造線西部を結ぶラインに数 $\mathrm{mm} /$ 年の右横ず れの変動があるとしている. また Sagiya et al. (2000) は GPS 連続観測により, 歪の蓄積速度が周囲よりも数 倍大きな幅数 10〜200 km の地域が新潟から関西地方 にかけて延びていることを明らかにしている．以上のよ うな数年〜100 年ほよ゙の測量結果から得られた地款変動 パターンと数千〜数十万年にわたる変動の累積を示す活 断層の変位パターンが一致するとは限らないが, 今回, 木落断層の活動度が $\mathrm{A}$ 級であることが明らかとなり， 今後, この変動帯に沿った右横ずれ断層群の活動や地震 活動について，再検討する必要があると思われる. 


\section{§6. まとめ}

木落断層の活動を明らかにするために, 地形判読・断 層地形の計測を行うとともに，断層露頭において変位の 計測, 埋没土壤の ${ }^{14} \mathrm{C}$ 年代測定等を行った結果, 以下の 点が明らかになった。

1）木落断層は南北に延びる長さ約 $3 \mathrm{~km}$ の逆断層で あり, 佐開では小扇状地面上に $2.5 \sim 4.0 \mathrm{~m}$ の西 落ちの段差が認められる.

2）佐開北方の土砂採取場では，基盤岩およびこれを 覆う砂磁層が, 走向 $\mathrm{N} 10 \sim 20^{\circ} \mathrm{W}$, 東傾斜 $20 \sim$ $30^{\circ}$ の逆断層に切られており, 基盤岩上面の垂直 変位量は $15 \mathrm{~m}$ 以上である.

3）砂礫層中の 3 層準に挟まれている埋没土壌の ${ }^{14} \mathrm{C}$ 年 代は上位より, 2,850 1,280 cal yBP (s3), 5,590〜 4,620 cal yBP (s2), 11,100 8,810 cal yBP (s1) で あり,この頃, 断層の活動があったと推定される.

4）埋没土壤を基準とした変位量は，断層のひきずり 変形屯含めて $\mathrm{s} 3$ では $3.3 \mathrm{~m}, \mathrm{~s} 2$ では $6.9 \mathrm{~m}, \mathrm{~s} 1$ で は 19〜20 m である.

5) 木落断層の単位変位量は $3 \sim 4 \mathrm{~m}$, 活動間隔は 2,500 4,500 年程度であり, $\mathrm{s} 1$ を基準としたと きの平均変位速度は $1.7 \sim 2.3 \mathrm{~m} / 1000$ 年と $\mathrm{A}$ 級 の活動度を示している。

6) 木落断層は左雁行状に連なる右横ずれ断層に伴う 逆断層であり， $\mathrm{B} \sim \mathrm{C}$ 級とされている周辺の断層 群の活動度について, 再検討が必要となった。

\section{謝辞}

本研究を進めるにあたり，佐開の合掌郁雄氏および (株) 兼井組には土砂採取場の調查を快く許可して頂い た.（株）ダイヤコンサルタントの松井和夫氏には放射性 炭素同位体測定において便宜を図っていただいた。福井 県立恐竜博物館の寺田和雄氏, 矢部 淳氏にはピット掘 削の協力, および断層露頭の永ぎ取り作業時の露頭写真 を提供していただいた． 福井大学教育地域科学部の服部 勇氏には粗稿に目を通していただいた。同中島正志氏， 藤井純子氏には有益な助言をいただいた．同地学教室の 学生の皆さんには露頭のクリーニングを手伝っていただ いた．また查読をしていただいた堤 浩之氏，岡本拓夫 氏からは適切な批評をいただいた。記して御礼申し上げ ます。なお,この研究を行うにあたり, 文部科学省科学 研究費補助金（基盤研究 C：課題番号 13640455）を一 部使用した。

\section{文献}

跡津川断層卜レンチ発掘調査団・岡田篤正・竹内 章・
佃 為成・池田安隆 - 渡辺満久 - 平野信一・升本真 二・竹花康夫・奥村晃史 - 神嶋（竹村）利夫 - 小林武 彦・安藤雅孝, 1989, 岐阜県宮川村野首における跡津 川断層のトレンチ発掘調査, 地学雑誌, 98, 440-463.

Hashimoto, M. and D. D. Jackson, 1993, Plate tectonics and crustal deformation around the Japanese Islands, J. Geophys. Res., 98, B9, 16149-16166.

Hattori, I. and H. Yamamoto, 1999, Rock fragmentation and particle size in crushed zone by faulting, J. Geology, 107, 209-222.

池田浩子・大八木規夫, 1997, 福井県大野市塚原野台地 に扔ける流机山の長軸方向の分布, 深田地質研究所報 告, no. 11,15 pp.

Kanaori, Y., S. Kawakami and K. Yairi, 1992, The block structure and quaternary strike-slip block rotation of central Japan, tectonics, 11, 47-46.

活断層研究会, 1980 , 日本の活断層一分布図之資料一, 東京大学出版会, $363 \mathrm{pp}$.

活断層研究会, 1991, 新編 日本の活断層一分布図と資 料一, 東京大学出版会, $437 \mathrm{pp}$.

町田 洋・新井 房夫, 2003, 新編 火山灰アトラス一 日本列島とその周辺一, 東京大学出版会, $336 \mathrm{pp}$.

三雲 健 - 和田博夫, 1983 , 跡津川断層と地震活動. 月 刊地球, 5, 325-334.

三村弘二, 2001, 福井県経ヶ岳火山南西麓の覆瓦構造を もつ塚原野岩屑なだれ堆積物と ${ }^{14} \mathrm{C}$ 年代, 地質調査研 究報告, 52, 303-307.

森本良平・松田時彦, 1961 , 北美濃地震被害地の地質 （第一報）福井県打波川上流～岐皁県石徹白川上流地 域, 地震研究所彙報, 39, 935-942.

村井 勇 - 金子史朗, 1975, 琵琶湖周辺の活断層系, 地 震研究所巢報, 50, 93-108.

中田 高・今泉俊文, 2002, 活断層詳細デジタルマッ $7^{\circ}$, 東京大学出版会, $60 \mathrm{pp}$, DVD-ROM.

䉆谷 威, 2001 , 日本列島を貫く歪の集中帯 新潟一神 戸構造帯, サイスモ， 5, 12 .

Sagiya, T., S. Miyazaki and T. Tada, 2000, Continuous GPS array and present-day crustal deformation of Japan, Pure Appl. Geophys., 157, 23032322.

Stuiver, M., P. J. Reimer, E. Bard, J. W. Beck, G. S. Burr, K. A.Hughen, B. Kromer, F. G. McCormac, J. van der Plicht and M. Spurk (1998) INTCAL98 radiocarbon age calibration, $24,000-0$ cal BP, Radiocarbon, 40, 1041-1083.

竹内文朗 ・平野憲雄, 1985 , 北陸微小地震観測所の震源 マップの概要について一約 1 万個の地震データのと りま之め一。京大防災研究所年報, no. 28, 157-170.

東郷正美・岡田篤正, 1983, 断層変位地形から見た跡津 川断層, 月刊地球, 5, 359-366.

山本博文 - 加藤亜季子, 1997, 福井県嶺北地域の活断 層, 福井大学積雪研究室研究報告「日本海地域の自然 之環境」, no. 4, 1-35.

山本博文・土田浩司, 2002, 塚原野台地の流屾山地形の 変遷, 福井大学地域環境研究教育センタ一紀要「日本 海地域の自然と環境」, no. 9, 93-100. 